\title{
Analysis The Influence Degree of Factors to Develop the Supporting Industry: Research in Thai Nguyen Province, Vietnam
}

\author{
Duong Quynh Lien \\ Thai Nguyen University - College of Economics and Techniques
}

\begin{abstract}
This study was conducted to analyze the influence degree of factors to develop supporting industry in Thai Nguyen province, Vietnam. Data for the study were collected from the survey of 116 supporting industrial enterprises operating in Thai Nguyen province. The analysis of the results showed that, the factors: Human resources, science and technology, capital, infrastructure, product consumption market has an influence on development of supporting industry, however, the degree of influence is different. On the basis of that analysis, the author proposes some recommendations to contribute to the development of supporting industry in Thai Nguyen province, Vietnam.
\end{abstract}

Keywords: Supporting industry, development, Vietnam

\section{Introduction}

Vietnam is being placed in a general context: globalization and regionalization is going strong, the fourth Scientific and Technological revolution is taking place, Vietnam itself is also transforming the development model in width to depth (from exploitation of mineral resources, take advantage of cheap labor trans to economic development mainly based on high productivity, using effectively resources and using advanced and modern science and technology.)

Along with the trend of developing industrial parks of the country as well as Northern midland and mountainous of Vietnam, Thai Nguyen province has advocated the synchronous construction of industrial parks in the overall socio-economic development plan of the country. In the end of 2016, Thai Nguyen province has six concentrated industrial parks: Song Cong 1, Song Cong 2, Nam Pho Yen, Tay Pho Yen, Quyet Thang and Diem Thuy.

These industrial parks have been formed and developed, contributing to economic restructuring, creating jobs for thousands of workers, developing the supporting and service industries of the province.

In the end of 2017, 182 projects have been granted investment certificates for industrial parks in the province with a total registered investment capital about USD 7,061 billion and about VND 14,192.72 billion; total implemented investment capital is about USD 6.4 billion and VND 7540.3 billion. [Source: Thai Nguyen Industrial Zone Authority]. 
In addition, the province is focused and invested in industrial development, leading to great demand about raw materials for production. For years, most enterprises in Thai Nguyen province use imported materials to produce finished products. Supporting industry in Thai Nguyen province in particular and in country in general has not met the demand about raw materials and accessories for domestic production both in quantity and quality. The above situation comes partly from objective reasons, that is the industry in Thai Nguyen province is still fledgling, the supporting industry is mainly based on foreign direct investment enterprises come to Thai Nguyen to rent premises, labors producing export products with most imported materials. However, the lack of investment planning to develop supporting industries as well as the lack of policies to encourage the development of supporting industries of the Central Committee for a long time, it is the main reason that the supporting industries in Thai Nguyen province in particular and in the country in general are underdeveloped. The dependence on imported raw materials and the underdeveloped supporting industry has influenced the growth quality of industries in Thai Nguyen province.

With that position, supporting industry not only receives the attention of policy makers but also receives the attention of researchers in the world as well as in the country. Research related to this area are aimed at clarifying issues related to supporting industry, namely, the concept of supporting industries in different countries and regions (Dung et al., 2014). Moreover, implementing research towards developing support industries, factors affecting the development of supporting industries. Some studies focus on analyzing policies affecting industrial development in general, investment in industrial development (Pham Thi Anh Nguyet (2014), Jackson and colleagues (1999)).

Therefore, studying the influence degree of factors to develop supporting industry is necessary.

\section{Research overview}

Supporting industry receives the attention not only of researchers but also of policy makers, the factors affecting supporting industry development are summarized as follows:

Table 1. Summary table about factors affecting development of supporting industry

\begin{tabular}{|l|l|}
\hline \multicolumn{1}{|c|}{ Items } & \multicolumn{1}{|c|}{ Author / year } \\
\hline Infrastructure system & Kamunge et al(2014); Trinh Duc Chieu et al(2010); \\
\hline $\begin{array}{l}\text { Supporting industrial development } \\
\text { policy }\end{array}$ & $\begin{array}{l}\text { Kamunge et al (2014); Bouazza et al (2015); Abrar- } \\
\text { ul-haq et al (2015); Trinh Duc Chieu et al (2010); } \\
\text { Quoc Nghi et al (2011); Phan Thi Minh Ly (2011); }\end{array}$ \\
\hline Human resources & $\begin{array}{l}\text { Ghosh et al (2011); Kamunge et al(2014); Bouazza } \\
\text { et al(2015); Abrar-ul-haq et al(2015); Trinh Duc } \\
\text { Chieu et al (2010); Đo Thi Thu Thuy (2017); Vu Chi } \\
\text { Loc (2010), Luu Tien Dung et al(2014) }\end{array}$ \\
\hline Product consumption market & $\begin{array}{l}\text { Chittithaworn et al (2011); Ghosh et al (2011); } \\
\text { Kamunge et al (2014); Bouazza et al (2015); Abrar- } \\
\text { ul-haq et al (2015); Trinh Duc Chieu et al (2010); } \\
\text { Nham Tuan et al (2016); Do Thi Thu Thuy (2017); } \\
\text { Vu Chi Loc (2010), Luu Tien Dung et al (2014). }\end{array}$ \\
\hline Capital (financial resource) & $\begin{array}{l}\text { Chittithaworn et al (2011); Ghosh et al (2011); } \\
\text { Kamunge et al (2014); Kamunge et al (2014); } \\
\text { Bouazza et al (2015); Abrar-ul-haq et al (2015); }\end{array}$ \\
\hline
\end{tabular}




\begin{tabular}{|l|l|}
\hline & Phan Thi Minh Ly (2011); \\
\hline Science and technology & $\begin{array}{l}\text { Ghosh et al (2011); Kamunge et al (2014); Bouazza } \\
\text { et al (2015); Abrar-ul-haq et al (2015); Trinh Duc } \\
\text { Chieu et al (2010); Phan Thi Minh Ly (2011); Nham } \\
\text { Tuan et al (2016); Do Thi Thu Thuy (2017) }\end{array}$ \\
\hline International integration & $\begin{array}{l}\text { Chittithaworn et al (2011); Phan Thi Minh Ly } \\
\text { (2011); Đỗ Thị Thu Thủy (2017); Vũ Chí Lộc (2010), } \\
\text { Luu Tien Dung et al (2014) }\end{array}$ \\
\hline Political, cultural and social & $\begin{array}{l}\text { Kamunge et al (2014); Trinh Duc Chieu et al (2010); } \\
\text { Vu Chi loc (2010), Luu Tien Dung et al (2014) }\end{array}$ \\
\hline
\end{tabular}

Source: Author's summary

\section{Research Methodology}

Primary information was collected from interviews with representatives of 116 enterprises in the supporting industry and related industries to supporting industries in Thai Nguyen province by the use of questionnaires. Research conducted to send survey forms to representatives of enterprises, in case of not meeting the representative of the enterprises; the author sent the survey form or sent an email and made an appointment a week later to return to receive the survey

With 116 enterprises that collected data to meet the minimum requirements of performing statistical operations.

After cleaning the data, the author performed OLS regression to analyze the influence of factors on supporting industry development in Thai Nguyen province, Vietnam under the help of SPSS 20.0 software.

\section{Research findings}

Dependent variable (Y): Results of investment in supporting industry development in Thai Nguyen province.

Independent variables:

+ Human resources (LD):

+ Supporting industrial development policy (CSPT)

+ Capital (V):

+ Product consumption market (TTTT):

+ Political, cultural and social

+ Infrastructure system (HT):

+ International integration (HN):

+ Science and technology (KHCN):

Research results are as follows: 
Table 1: Testing the level of model interpretation

\begin{tabular}{|l|l|l|l|l|}
\hline \multicolumn{2}{|l|}{ Model Summary } & R Square & Adjusted R Square & $\begin{array}{l}\text { Std. Error of the } \\
\text { Estimate }\end{array}$ \\
\hline 1 & R & .770 & .752 & .452016626694024 \\
\hline a. Predictors: (Constant), V, HT, HN, CSPT, XH, KHCN, LD, TTTT & \\
\hline
\end{tabular}

Source: Result analysis from the author's research data

The level of model interpretation, with adjusted $\mathrm{R} 2$ coefficient $=0.752$, this indicates that about $75.2 \%$ of the variation of the dependent variable is explained by the independent variables in the model.

Table 2: Testing the relevance of the model

\begin{tabular}{|l|l|l|l|l|l|l|}
\hline \multicolumn{7}{|c|}{ ANOVA } \\
\hline \multirow{2}{|c|}{ Model } & Sum of Squares & df & Mean Square & F & Sig. \\
\hline \multirow{4}{*}{1} & Regression & 73.014 & 8 & 9.127 & 44.669 & $.000^{\text {b }}$ \\
\cline { 2 - 7 } & Residual & 21.862 & 107 & .204 & & \\
\cline { 2 - 7 } & Total & 94.876 & 115 & & \\
\hline \multirow{2}{*}{ a. Dependent Variable: KQ } & & & \\
\hline \multirow{2}{*}{ b. Predictors: (Constant), V, HT, HN, CSPT, XH, KHCN, LD, TTTT } & \\
\hline
\end{tabular}

Source: Result analysis from the author's research data

With Sig coefficient $=0.000$ the author's research model is suitable.

Table 3: Regression results model

\begin{tabular}{|c|c|c|c|c|c|c|c|c|}
\hline \multicolumn{9}{|c|}{ Coefficients } \\
\hline & & \multicolumn{2}{|c|}{$\begin{array}{l}\text { Unstandardized } \\
\text { Coefficients }\end{array}$} & \multirow{2}{*}{\begin{tabular}{|l|} 
Standardized \\
Coefficients \\
Beta
\end{tabular}} & \multirow[b]{2}{*}{$\mathrm{t}$} & \multirow[b]{2}{*}{ Sig. } & \multicolumn{2}{|c|}{$\begin{array}{l}\text { Collinearity } \\
\text { Statistics }\end{array}$} \\
\hline \multicolumn{2}{|c|}{ Model } & $\mathrm{B}$ & Std. Error & & & & Tolerance & VIF \\
\hline \multirow[t]{9}{*}{1} & (Constant) & -2.641 & .375 & & -7.037 & .000 & & \\
\hline & LD & .231 & .075 & .174 & 3.075 & .003 & .676 & 1.480 \\
\hline & CSPT & .217 & .047 & .247 & 4.574 & .000 & .737 & 1.356 \\
\hline & $\mathrm{HN}$ & .239 & .051 & .222 & 4.724 & .000 & .974 & 1.027 \\
\hline & HT & .211 & .050 & .246 & 4.176 & .000 & .620 & 1.613 \\
\hline & KHCN & .285 & .056 & .305 & 5.088 & .000 & .599 & 1.671 \\
\hline & $\mathrm{XH}$ & .186 & .066 & .155 & 2.817 & .006 & .714 & 1.401 \\
\hline & TTTT & .185 & .067 & .183 & 2.768 & .007 & .492 & 2.031 \\
\hline & $\mathrm{V}$ & .163 & .068 & .142 & 2.419 & .017 & .629 & 1.589 \\
\hline
\end{tabular}

Source: Result analysis from the author's research data

+ Human resources (LD): The coefficient of the labor variable 0.231 is positive (+) Indicates the relationship in the same direction of independent variables and dependent variables. When 
assessing the local labor force increased by 1 point, the development result of supporting industrial enterprises will increase by 0.231 points.

+ Supporting industrial development policy (CSPT): The coefficient of CSPT variable 0.217 is positive $(+)$ also shows the positive relationship of the independent variable and the dependent variable. When evaluating the supporting industry development policy by 1 point, the development result of supporting industrial enterprises will increase by 0.217 points.

+ International integration (HN): The analysis results show that the coefficient of the international integration variable is positive, express the relationship of independent variables and dependent variables, specifically, the coefficient of this variable is 0.239 , indicating that when assessing international integration by 1 point, the development result of supporting industrial enterprises will increase by 0.239 points.

+ Infrastructure system (HT): The coefficient of the infrastructure system variable is 0.211 with positive sign (+) also shows the positive relationship of the independent variable and the dependent variable. When assessing infrastructure system by 1 point, the development result of supporting industrial enterprises will increase by 0.211 points.

+ Science and technology (Science and Technology): The analysis results show that the coefficient of scientific and technological variables is positive, expressing the reciprocal relationship of the independent variable and the dependent variable, namely the coefficient of this variable is 0.285 indicating that when evaluating science and technology increased by 1 point, the development result of industrial enterprises support will increase by 0.285 points.

+ Political, cultural and social $(\mathrm{XH})$ : The coefficient of $\mathrm{XH}$ variable 0.186 with positive sign $(+)$ also shows the positive relationship of the independent variable and the dependent variable. When favorable political, cultural and social environment will contribute to the improving output result in a positive way of supporting industry enterprises..

+ Product consumption market (TTTT): The analysis results show that the coefficient of the consumption market variable is positive, showing the positive relationship of the independent variable and the dependent variable. Specifically, the coefficient of this variable is 0.185 , which indicates that when evaluating the consumption market of the product increases 1 point, the development result of the supporting industry will increase by 0.185 points.

+ Capital (V): The analysis results show that the coefficient of the variable is positive, showing the positive relationship of the independent variable and the dependent variable, namely the coefficient of this variable is 0.163 indicating that when In assessing capital increase by 1 point, the development result of supporting industrial enterprises will increase by 0.163 points.

\section{Conclusion}

Research findings have shown the difference in the influence degree of factors on supporting industry development, it seems that the science and technology and the integration factor have the greatest influence to develop supporting industry in Thai Nguyen province, Vietnam. Research findings are used as a basis for proposing recommendations to contribute to develop supporting industries in Thai Nguyen province.

\section{Recommendations}

To develop supporting industries for Thai Nguyen province in the coming time, the solutions need to be implemented synchronously as follows:

Firstly, investing in developing infrastructure system

Secondly, ensuring capital sources for supporting industry development 
Third, training human resources to meet the needs of enterprises in the supporting industry in the province

Fourth, investing and innovating in technological

Fifthly, strengthening international integration, facilitating the expansion of product consumption market

Eighth, taking advantage of local

\section{References}

Abrar ul haq M., Razani M. J., \& Nurul M. G. I. (2015). “Factors Affecting Small and Medium Enterprises (SMES) Development in Pakistan", American Eurasian J. Agric. E Environ. Science, 15 (4), pp 546 - 552.

Ministry of Industry (2007), Approval decision the planning for development of supporting industry by 2010, vision to 2020

Bouazza A. M. (2015), "Establishing the Factors Affecting the Growth of Small and Mediumsized Enterprises in Algeria", American International Journal of Social Science, 4 (2), pp 101 115

Chittithaworn C. (2011), "Factors affecting business success of small \& medium enterprises (SMEs) in Thailand", Asian Social Science, 7 (5), pp 180-190.

Thai Nguyen Statistical Office (2018), Thai Nguyen Statistical Supervision in 2017.

Do Thi Thu Thuy (2017), Impact of supporting industry on attracting foreign direct investment into Vietnam - research in Vinh Phuc province, Economic doctoral dissertation, National Economics University, Hanoi.

Ghosh B. C. and Kwan C. (2010), an analysis of key success factors of SMEs: A comparative study of Singapore/Malaysia and Australia/New Zealand, in The 41 st ICSB World Conference Proceedings I, 215-252, Stockholm, Sweden, June 16-19.

Hair J. J. F., Anderson R. E., Tatham R. L., \& Black W. C. (2006). Multivariate Data Analysis. (7th ed.): Peason Prentice Hall.

Kamunge S. M., Njeru A., \& Tirimba I. O. (2014), "Factors affecting the performance of small and micro enterprises in Limuru Town market of Kiambu County", International Journal of Scientific and Research Pubications, 12 (4), pp 1-20

Luu Tien Dung et al (2014), Factors affecting the development of Dong Nai mechanical engineering supporting industry, Proceedings of the Scientific Conference Combined 2014, Danang University of Economics.

Mashenece G. R., \& Rumanyika J. (2014), “Business constraints and potential growth of small and medium enterprises in Tanzania: A review", Euro Journal of Business and Management, 32 (6), pp 55-61.

Mori, J. (2005). Development of supporting industries of Vietnam's industrialization: Increasing positive positive vertical externalities through collaborative training. Master. The Fletcher School, Tufts University, USA.

Nguyen Quoc Nghi, Mai Van Nam (2011), "Factors affecting business performance of small and medium enterprises in Can Tho city", Science Journal, Can Tho University, p. 122-129 
Nham Tuan, Nguyen Nhan, Pham Giang, Nguyen Ngoc (2016). The Effects of Innovation on Firm Performance of Supporting Industries in Hanoi - Vietnam. Journal of Industrial Engineering and Management. JIEM, 2016-9(2):314-431- Online ISSN: 2013-0953.

Phan Thi Minh Ly (2011), "Analysis the impact of factors affecting the business operations of small and medium enterprises in Thua Thien Hue", Science and Technology Journal, Da Nang University, 43 (2), p 151 - 157

Phan Van Hung (2015), Developing supporting industry in civil construction industry in Vietnam, Economic doctoral dissertation, National Economics University, Hanoi.

Ragsdale C.T (2007). Modeling \& Decision Analysis. Revised edition. Boston: Cengage Learning.

Ratana E (1999), the role of small and medium supporting industries in Japan and Thailand, IDE APEC.

Thainguyen Administration of commerce and Industry (2018) Project to support supporting industry in Thai Nguyen province till 2025, with vision to 2030.

Prime Minister (2011), Decision No. 12/2011 / QD-TTg of the Prime Minister on supporting industry development policy.

Thuy, N.T.X (2006). Supporting industries: A review of concept and development. Tokyo, Vietnam Development Forum. 27-50

Trinh Duc Chieu (2010), The main factors affecting the development of small and medium enterprises in Vietnam - Quantitative assessment through a survey of Danida 2005 - 2009, Ministerial-level Scientific Research, Central Institute for Economic Management, Ministry of Planning and Investment

Vu Chi Loc (2010), The role of Transnational Corporations (TNCs) in the development of supporting industries in developing countries, Trade Journal, No. 19. 